TILTAI, 2021, 2, 14-38 ISSN 1392-3137 (Print), ISSN 2351-6569 (Online); DOI: 10.15181/tbb.v87i2.2315

\title{
DARBUOTOJŲ FINANSINIO DALYVAVIMO LIETUVOJE RAIDA IR FORMOS: İMONIŲ AKCIJŲ IR PELNO PASIDALIJIMO PROGRAMOS BEI PRIEMONĖS
}

\author{
Remigijus Civinskas, Rimantas Stašys \\ Vytauto Didžiojo universitetas, Klaipédos universitetas (Lietuva)
}

\begin{abstract}
Anotacija
Straipsnyje analizuojama darbuotojų finansinio dalyvavimo Lietuvoje raida, vertinama finansinio dalyvavimo teisinė aplinka, šio dalyvavimo paramos politika. Darbuotojų finansinio dalyvavimo temos analizè atlikta taikant du metodus: 1) loginès analizės, nagrinėjant įmonių vidaus dokumentus; 2) kokybinio tyrimo bandomosios grupès ir iš dalies struktūruoto individualaus interviu. Surinktų duomenų analizei atlikti pasitelktos agentūros ir remtasi suinteresuotų veikẻjų teorijomis. Pastarosios moksliniuose tyrimuose dažniausia taikomos integruotai, analizuojant darbuotojų finansinį dalyvavimą, siekiant išsiaiškinti jų nuosavybès reiškinį, nagrinèjant ịgaliotinio veikimą. Nustatyta, kad Lietuvoje dažniausia taikomos keturios darbuotojų akcijų nuosavybès programos ir planai: plačios darbuotojų akcijų opcionų programos (suteikiamos akcinėms bendrovėms, kurių akcijomis prekiaujama vertybinių popierių biržose); darbuotojų akcijų opcionų skyrimas vadovams (vadinamieji vadovu akciju opcionai, programos ir vienkartiniai sprendimai); akcijų opcionų programos startuoliu imonėse; akcininkų darbuotojams suteikiamos akcijos.

PAGRINDINIAI ŽODŽIAI: darbuotojų finansinis dalyvavimas, akcijų opcionas, agentūros teorija, suinteresuoti veikèjai.
\end{abstract}

\begin{abstract}
The article analyses the development of employee financial participation in Lithuania, describes the legal environment of financial participation, and supports this participation. Two methods were used to analyse employee financial participation: 1) the method of logical analysis in examining the internal documents of companies; 2) the qualitative research methods of focus group and semi-structured individual interviews. Theories of the agency and stakeholders were used to analyse the data collected. These theories are usually applied in research in an integrated way, analysing employee financial participation to elucidate the phenomenon of employee ownership, and examining the agent's performance. It has been established that in Lithuania four employee share ownership programmes and plans usually apply: extensive employee share option programmes (granted to public limited companies whose shares are traded on stock exchanges); granting employee stock options to executives (so-called executive stock option programmes and one-time decisions); stock option programmes in start-ups; and shares granted by shareholders to employees.

KEY WORDS: employee financial participation, stock option, agency theory, stakeholders.
\end{abstract}

DOI: http://dx.doi.org/10.15181/tbb.v87i2.2315

\section{Ivadas}

Darbuotojų finansinis dalyvavimas, dalijantis su darbuotojais pelnu arba nuosavybe, yra dažnas socialinis reiškinys Vakarų Europos bendrovèse (Kim, Patel, 2017). Lietuvoje jis mažiau populiarus, ypač kai siejamas su ilgalaikėmis ịmonių 
akcijų suteikimo darbuotojams programomis (Civinskas, Dvorak, 2017; 2019). Lietuvoje darbuotojų finansinis dalyvavimas dažniausia vyksta per akcijų opcionus arba darbuotojų pasirinkimo sandorius. Tai lèmė ịmonès siekis išlaikyti kvalifikuotus ir patyrusius darbuotojus, juos motyvuoti produktyviai dirbti, siekti geru rezultatų bei išlikti lojaliais įmonei.

Mokslininkai, verslo ekspertai ir politikai sutaria, kad nagrinejjama darbuotojų dalyvavimo valdant ịmones forma naudinga ne tik darbuotojams, bet ir ịmonèms. Darbuotojų nuosavybės koncepcija pagrịsta darbuotojo savininko idejja (Aubert ir kt., 2017; Whitfield ir kt., 2017). Darbuotojai, būdami savininkais, daugiau pajamų gali gauti iš dividendų. Tai juos motyvuoja siekti geresnių įmonès veiklos rezultatų (Lowitzsch ir kt., 2017). Tiesa, yra ir vidinių veiksnių bei organizacinių aplinkybių, kurios lemia darbuotojų finansinio dalyvavimo schemos galimą neveiksmingumą.

Per pastaruosius dešimtmečius darbuotojų finansinio dalyvavimo tema sulaukè nemažai mokslininkų dėmesio. Ji tapo tarpdisciplininiu tyrimo objektu. Darbuotojų finansinį dalyvavimą nagrinėja ne tik ekonomistai (Bryson ir kt., 2012), žmogiškujų išteklių vadybos specialistai (Poutsma ir kt., 2017; Poutsma, Kaarsemaker, 2015), bet ir viešosios politikos (Lowitzsch, 2009) bei verslo etikos tyrinètojai (Freeman ir kt., 2009; Reynolds, 2014; Shipper, 2014). Viena ryškiausių tyrimo krypčių susijusi su darbuotojų įtraukimu, siekiant motyvuoti ir užtikrinti lojalumą imonei. Mokslininkai analizuoja darbuotojų ir darbdavių santykius bei sąveiką, ịtraukiant darbuotojus ị sprendimų prièmimo procesą, kuris susijęs su įmonès finansiniais rezultatais.

Darbdavių sukurtos darbuotojų ịtraukimo schemos tikslas - siekti, kad ịmonės veiklos rezultatai būtų aktualūs darbuotojams. Be to, jie gali derinti asmeninius ir įmonès veiklos rezultatus. Akademiniame lauke ryški tyrimų tematika, kurioje nustatomas ryšys tarp darbuotojų nuosavybės ir įmonės veiklos veiksmingumo (Kim, Patel, 2017). Dalis atliktų empirinių tyrimų atskleidè ryšius tarp įmonès veiklos rezultatų (darbuotojų produktyvumas, finansiniai rezultatai, personalo valdymo stabilumas) ir darbuotojų finansinio dalyvavimo (Kang, Kim, 2019; Kurtulus, Kruse, 2018; Richter, Schrader, 2017; Whitfield ir kt., 2017).

Tyrimų išvadose dažnai akcentuojama, kad darbuotojų akcijų taikymas yra kompleksinis reiškinys, tad išskirti vienareikšmes naudas išties sudètinga. Kai kurie tyrimai nurodo neigiamą darbuotojų finansinio dalyvavimo poveikị įmonès veiklai, nes darbuotojai akcininkai vadovaujasi siaurais interesais ir naudos siekiu, mažèja investicijų i tyrimus ir plètrą, netinkamai valdomos rizikos (Aubert ir kt., 2017; Faleye ir kt., 2006). Paprastai „tamsioji darbuotojų nuosavybės“ formos pusè pastebima tada, kai darbuotojai, siekdami asmeninès naudos, ima vadovautis vien asmeniniais interesais (Guedri, Hollandts, 2008). 
Kita mokslinių darbuotojų finansinio dalyvavimo tyrimų kryptis siejama su papildomų investicijų pritraukimu. Dažniausia tai aktualu startuolių įmonėms. Rizikos kapitalo investuotojai paprastai suinteresuoti veiksmingomis darbuotoju paskatomis (Geczy ir kt., 2016).

Darbuotojų finansinis dalyvavimas - tiek pelno pasidalijimo, tiek ir darbuotojų akcijų pasidalijimo formomis - kelis dešimtmečius pamažu augo (2014 m. lyginamosios studijos duomenys) (Lowitzsch, Hashi, 2014). Darbuotojų nuosavybės plètrą patvirtina ir darbuotojų nuosavybès federacijos 2020 metais pateikta ataskaita (Mathieu, 2021), kurioje teigiama, kad 2020 m. net 94 proc. visų didelių Europos bendrovių turèjo darbuotojų akcijų. Kita vertus, ši tendencija pastebima ne visose šalyse. Pavyzdžiui, Lietuvoje, kaip ir kai kuriose kitose Baltijos šalyse, darbuotojų, disponuojančių akcijomis, skaičius mažèjo. Darbuotojų ịgytos ịmonių akcijos, privatizuojant valstybės ar savivaldybès ịmones, vèliau perduotos įmoniu savininkams.

Tyrimo objektas - darbuotojų finansinis dalyvavimas Lietuvos įmonėse.

Straipsnio tikslas: ištyrus darbuotojų finansinio dalyvavimo Lietuvoje teisinę aplinką ir formas, ịvertinti finansinio dalyvavimo Lietuvos įmonèse raidos galimybes.

Uždaviniai:

1. Apibūdinti darbuotojų finansinio dalyvavimo Lietuvoje teisinę aplinką ir paramos politiką.

2. Nustatyti darbuotojų finansinio dalyvavimo Lietuvoje dažniausia taikomas programas ir planus.

3. Ivertinti darbuotojų finansinio dalyvavimo Lietuvoje raidos galimybes.

\section{Darbuotojų finansinio dalyvavimo tyrimo metodika, duomenų analizès teorinės prielaidos}

Iš viso atlikta 19 iš dalies struktūruotų individualių anoniminių (iš kurių 16 telefonu ir tik 3 - tiesioginio susitikimo metu) ir vienas grupinis interviu. Interviu metodas pasirinktas kaip tinkamas, siekiant surinkti numatytus duomenis (apie darbuotojų akcijų ir pelno padalijimo programų taikymą, jų turinị ir t. t.), ir svarbus analizuojant informantų nuomones. Šis metodas gali būti veiksmingas, siekiant paskatinti informantus atskleisti savo požiūrị ir patirtị, susijusią su darbuotojų finansiniu dalyvavimu. Be to, jis supažindina su darbuotojų dalyvavimo programų ir pavienių planų taikymo praktikomis, darbuotojų ịtraukimo ị ịmonių valdymą, motyvavimo ir lojalumo užtikrinimo poveikiu. Interviu su informantais atskleidè ir kitas problemas: darbuotojų ir verslo įmonių informuotumo, finansinio dalyvavimo, jo taikymo praktikos. 
Prieš atliekant interviu paruoštas tyrimo dizainas, apimantis keturias pagrindines temas, kurios susijusios su darbuotojų finansiniu dalyvavimu: 1) schemų taikymo tikslai ir paskatos (darbuotojų ir darbdavių interesai, jų derinimas, viešosios politikos veikèjai); 2) formų ir būdų pasirinkimas bei adaptavimas įmonèse; 3) darbdavių požiūriai ị darbuotojų finansinị dalyvavimą. Pagal šias temas véliau atliktas kodavimas. Siekiant išanalizuoti individualaus interviu ir bandomosios grupès tyrimo metu surinktus duomenis, tas pats pagrindinių klausimų dizainas taikytas ir bandomosios grupès tyrimo metu.

Sudarant informantų imtị taikyti keli kriterijai. Pirma, interviu siekta gauti iš kompetentingų įmonių atstovų - įmonių žmogiškujjų išteklių ir finansų padalinių vadovų, teisès padalinių vadovų arba teisès įmonių, atstovaujančių jiems, aukščiausių įmonės vadovų (žr. 1 lentelę). Antra, informantai pasirinkti pagal keturis kriterijus. Dèl relevantiškumo temai interviu atlikti su 1) finansų (bankai, investiciniai fondai, draudimo bendrovès ir t. t.) ir 2) startuolių įmonių atstovais; 3) atsirinktos įmonès, taikančios darbuotojų akcijų programas arba pelno pasidalijimo schemas; 4) ị kokybinị tyrimą ịtrauktos ir tarptautinès korporacijos, kurių vadinamosios motininės įmonès taiko darbuotojų akcijų programas (neatsižvelgta ị tai, ar jos programas perkelia ị dukterines ịmones Lietuvoje).

1 lentele. Interviu tyrimo informantai

\begin{tabular}{|l|l|l|l|l|}
\hline Nr. & Pareigos & Imonès veiklos sektorius & Imonės dydis & Kodas \\
\hline 1 & Žmogiškujų išteklių vadovas & Finansai ir bankai & $\sim 1500$ darb. & INF1 \\
\hline 2 & Žmogiškujų išteklių vadovas & Finansai ir bankai & $\sim 100$ darb. & INF2 \\
\hline 3 & Žmogiškujų išteklių vadovas & Finansai ir bankai & $\sim 1000$ darb. & INF3 \\
\hline 4 & Generalinis direktorius & Prekyba & $\sim 30$ darb. & INF4 \\
\hline 5 & Ekonomistas & Prekyba & $\sim 30$ darb. & INF5 \\
\hline 6 & Darbuotojas & Prekyba & $\sim 50$ darb. & INF6 \\
\hline 7 & Žmogiškųų išteklių vadovas & Energetika & $\sim 10$ darb. & INF7 \\
\hline 8 & Vadovas & Prekyba ir paslaugos & $\sim 50$ darb. & INF8 \\
\hline 9 & Žmogiškujų išteklių vadovas & Prekyba & $\sim 100$ darb. & INF9 \\
\hline 10 & Žmogiškųų išteklių vadovas & Prekyba & $\sim 150$ darb. & INF10 \\
\hline 11 & Finansų vadovas & Gamyba ir prekyba & $\sim 1500$ darb. & INF11 \\
\hline 12 & $\begin{array}{l}\text { Atlyginimų kintamosios } \\
\text { dalies padalinio vadovas }\end{array}$ & Paslaugos & $\sim 1500$ darb. & INF12 \\
\hline 13 & Žmogiškujų išteklių vadovas & Prekyba ir paslaugos & $\sim 130$ darb. & INF13 \\
\hline 14 & Generalinis direktorius & Prekyba ir paslaugos & $\sim 100$ darb. & INF14 \\
\hline 15 & İmonėje dirbantis teisininkas & Gamyba & $\sim 30$ darb. & INF15 \\
\hline 16 & Teisininkas & $\begin{array}{l}\text { Atstovaujantis kelioms } \\
\text { imonėms }\end{array}$ & & INF16 \\
\hline 17 & $\begin{array}{l}\text { Vadovas, savininkas, steigè- } \\
\text { jas }\end{array}$ & IT & $\sim 50$ darb. & INF17 \\
\hline
\end{tabular}


Remigijus Civinskas, Rimantas Stašys

\begin{tabular}{|l|l|l|l|l|}
\hline Nr. & Pareigos & İmonès veiklos sektorius & İmonès dydis & Kodas \\
\hline 18 & Žmogiškųjų išteklių vadovas & Gamyba & $\sim 10$ darb. & INF18 \\
\hline 19 & Vadovas & IT & $\sim 30$ darb. & INF19 \\
\hline
\end{tabular}

Atsirenkant informantus atsižvelgta ir į aptiktą informaciją, kad įmonès taiko darbuotojų akcijų programas arba pelno padalijimo darbuotojams schemas. Be to, svarbiu įmonių inovatyvumo įtraukiant darbuotojus požymiu laikomi faktai apie socialinès atsakomybès filosofiją ir vadybos priemonių taikymą, įmonių tvaraus verslo filosofiją. Deja, nepavyko atsirinkti visų įmonių, kurios taiko plačiąsias darbuotojų akcijų programas (akcijos padalijamos ne tik vadovams ar vadovaujantiems asmenims). Pastebètina, kad tokios praktikos neregistruojamos ar informacija kitaip nerenkama. Sudarant imtị atsižvelgta ir ị įmonių dydị: ịtraukti didelių, vidutinių, mažų ir labai mažų įmonių atstovai.

Individualių interviu trukmè - nuo 20 minučių iki valandos. Interviu vykdyti 2019-2020 m. m. telefonu arba susitikus su informantais. Interviu metu pasitelkti užrašai, daromas skaitmeninis įrašas (dẻl techninių kliūčių kelių interviu ịrašai neišliko). Interviu buvo anoniminiai, nes to pageidavo dauguma dalyvių, teigusių, kad anonimiškai galètų atviriau dalintis informacija. Interviu užrašinètas, atlikti ir garso įrašai, kurie yra saugomi. Gauti interviu transkribuoti, jų duomenys analizuoti remiantis temine analize, kuri derinta su organizaciniais tyrimais ir interviu atlikimo technikomis (Cassell, Bishop, 2019).

Kokybinio tyrimo ribojimai. Kartais informantai (ypač atstovaujantys uždarojo tipo bendrovėms) negalëjo atskleisti visų detalių apie įmonėse taikomas darbuotojų finansinio dalyvavimo programas. Šis apribojimas aiškintas įmonès paslaptimi. Kitas apribojimas susijęs su ribotu darbuotojų finansinio dalyvavimo supratimu. Pavyzdžiui, dauguma informantų gerai žinojo vieną darbuotojų pelno pasidalijimo būdą (dažniausia kintamojo atlyginimo dydžio programos, kuriose atlyginimo priedai skiriami nuo įmonių metinio pelno ir išmokami grynaisiais arba akcijų opcionais), kiti buvo mažiau žinomi. Didžiausia kokybinio tyrimo kliūtimi tapo kai kurių informantų (imonių aukščiausių vadovų, finansų ir personalo valdymo padalinių vadovų) pasiekiamumas. Šie informantai gavo informaciją (tai daryta siunčiant oficialų prašymą-kvietimą, pakartotinai skambinta ir teirautasi el. pašto administratoriaus, persiųsta ar žodžiu perduota informacija). Be to, kreiptasi per socialinị tinklą „LinkedIn“, galimi informantai neatsakẻ ị užklausas arba netiesiogiai gauta informacija, kad jie yra labai užimti.

Analizuojant surinktus kokybinio tyrimo duomenis pasitelktos agentūros (igaliotinio), remtasi suinteresuotų veikèjų teorijomis, kurios paprastai taikomos siekiant integruotai analizuoti darbuotojų finansinị dalyvavimą bei nustatyti šio reiškinio poveikị darbuotojų sprendimams ir motyvams. 
Suinteresuotų veikèjų teorija teigia, kad organizacijos yra atsakingos už skirtingų suinteresuotų veikejjų (klientų, darbuotojų, verslo partnerių, valdžios institucijų, vietos bendruomenių ir pan.) interesų tenkinimą (Freeman ir kt., 2010; Edward Freeman, 2010). Suinteresuotų veikejjų valdymas yra tam tikrų trijų komponentų derinys: geras ịmonės valdymas (akcininkų interesų apsauga), veiksmingi suinteresuotų veikèjų ryšiai (jų interesų apsauga), aplinkos apsauga (Edward Freeman, 2010; Renneboog ir kt., 2008). Kadangi darbuotojai įmonėms yra svarbūs kaip suinteresuoti veikejjai, įmonių savininkai (pagrindiniai akcininkai) siekia suderinti darbuotojų ir įmonės interesus (Elouadi ir kt., 2016). Dalies nuosavybės perdavimas ịmonès darbuotojams yra puikus būdas tuos interesus suderinti.

Teoretikai diskutuoja, kaip tikslingai taikyti finansinio darbuotojų dalyvavimo būdus ir technikas, kad jie taptų tinkamais suinteresuotais veikejjais. Daugelis suinteresuotų veikejjų teorinę prieigą taikiusių mokslininkų patvirtino teigiamus rezultatus (Lamberg ir kt., 2003; Thompson ir kt., 2014; Zattoni, 2011). Ši prieiga leidžia analizuoti ir kitu suinteresuotų veikèjų - darbuotojų atstovų (profesinių sajungų, darbo tarybų), valdžios interesus ir jų atitikimą įmonès interesams. Tiesa, kai kuriuose tyrimuose nurodyti trūkumai, susiję su netinkamų darbuotojų finansinio dalyvavimo schemų pasirinkimu, perdèm plačiu jų taikymu, paskatų nesuderinamumu ir t. t. (Brandes ir kt., 2003; Damiani, 2009). Galiausiai ši teorija ribota, aiškinantis darbuotojų finansinio dalyvavimo ir įmonès valdymo organizacinius kontekstus. Be to, ji nepaaiškina darbuotojo elgesio kaitos aplinkybių ir veiksnių. Ją puikiai papildo agentūros teorija.

Agentūros teorija. Agentūros elgesio modelis susieja vidinius įmonès valdymo elementus, kad paaiškintų vadovų elgesị jiems priimant rizikingus sprendimus (Wiseman, Gomez-Mejia, 1998). Šis požiūris kitaip dar vadinamas užsakovo ir igaliotinio teorija. Jos plètotojai mano, kad savininkų teises ir kontrolę atskiriančios organizacijos patiria papildomus kaštus (Fama, Jensen, 1983). Igaliotinio (darbuotojo ar darbuotojų) problema kyla nesuderinus jo ir užsakovo (įmonės savininkų) tikslų. Tokiu atveju dèl moralinès rizikos (angl. moral hazard) (asmeninio suinteresuotumo, riboto racionalumo, nenoro rizikuoti) gerokai išauga igaliotiniu stebėjimo sąnaudos. Darbuotojų elgseną stebèti užsakovui tampa sudètingiau, sumažinus organizacijos hierarchijos struktūrą. Tokiu atveju darbuotojų įtraukimas finansiškai ịgalina jų nukreipimą ị ịmonès veiklos rezultatus. Taip jie tampa įmonès, kaip užsakovo, igaliotiniais. Šiuo atveju darbuotojų atlyginimų ir įmonès veiklos rezultatų sąsajos suderina užsakovo ir igaliotinio interesus.

Užsakovo ir ịgaliotinių susitarimai dẻl pelno ar nuosavybės padalijimo yra sutartys, kurios leidžia spręsti tris įmonėse pasitaikančias problemas: 1) dalinị tikslų konfliktą; 2) veiksmingumą; 3) informacijos asimetriją. Tačiau šios teorijos kritikai pastebi, kad darbuotojų finansinis dalyvavimas gali būti nepakankamai veiks- 
minga paskata (Kroumova, Sesil, 2006; Wagner ir kt., 2003). Be to, nemaža dalis empirinių studijų didesnio ryšio tarp finansinio dalyvavimo schemų taikymo ir įmonès veiklos rezultatų nerodo.

Kita vertus, ši teorija yra svarbi analizuojant įmonès nuosavybès perdavimą vadovaujantiems darbuotojams. Mokslininkai ir praktikai diskutuoja, ar vadovų „apdovanojimas“ (integravimas ị kintamas atlyginimų sistemas) akcijomis tinkamai formuoja jų elgseną. Pavyzdžiui, kai kurie tyrinėtojai teigia, kad akcijų opcionai (kaip paskatų sistema) mažina vadovaujančių asmenų siekị priimti rizikingus sprendimus (Baixauli-Soler ir kt., 2015; Jaffee, Freeman, 2000; Martin ir kt., 2013; Sahakiants, Festing, 2019). Tiesa, klasikinès agentūros teorijos sekèjų prielaidos būdavo priešingos.

\section{Darbuotojų finansinio dalyvavimo Lietuvoje teisinis reglamentavimas ir parama}

Darbuotojų finansinio dalyvavimo, kaip reiškinio, istorinè raida gana permaininga, grupuotina ị keturis laikotarpius: 1) privatizacijos (1991-1999 m.); 2) po privatizacijos (1999-2008 m.); 3) finansinès krizès (2009-2014 m.); 4) valstybès paramos politikos (2015-2018 m.). Mokslininkai yra pakankamai ištyrę pirmuju laikotarpių bruožus Vidurio ir Rytų Europos kontekste. Pastebèta, kad sudarytos teisinès darbuotojų akcijų ịsigijimo sąlygos (nors veikè planai individualiu ir įmonès lygmenimis) (Darškuvienė, Vazniokas, 2006; Mygind, 1997; 2012). Šios sąlygos vẻliau šiek tiek keistos, sudarant darbuotojų nuosavybės planų taikymo sąlygas (antrasis ir trečiasis etapai). Vis dèlto Lietuvoje (kaip ir kitose šalyse) darbuotojų finansinio dalyvavimo paramos politika nesusiformavo, nes ši sritis kaip aktuali problema netraktuota. Tai lèmẻ keletas esminių priežasčių: Lietuvos kapitalizmo, socialinès ir ekonominès raidos pobūdis, neigiami privatizacinio laikotarpio poveikiai (pvz., mažas poveikis produktyvumui, neigiami darbuotojų požiūriai) (Civinskas, Dvorak, 2019; Jones, Mygind, 2000).

2015-2016 m. darbuotojų akcijų reglamentavimo spragų problemas ėmè kelti užsienio kapitalo bankai ir finansinès organizacijos. Jie buvo ịpareigoti perkelti savo akcijų padalijimo darbuotojams programas iš vadinamujų motininių ịmonių Skandinavijoje ị vadinamąsias dukterines Lietuvoje, tačiau susidūrè su nepalankia mokestine aplinka, taikoma akcijų opcionų planams (Civinskas, Dvorak, 2017). 2015-2016 m. teisinio reglamentavimo politikos kaitos procese dalyvavo Lietuvos bankas, LR finansų ir LR ūkio ministerijos. Teisinio reguliavimo peržiūrai buvo sukurta darbo grupé (Lietuvos Respublikos Akcinių bendrovių įstatymo Nr. VIII-1835 2, 15, 20, 28, 32, 34, 37, 38, 45, 46, 47, 51, 52, 54, 57 ir 59 straipsniu pakeitimo ir ịstatymo papildymo 471 ir 472 straipsniais ịstatymo projekto aiškina- 
masis raštas, n. d.). 2016 m rengiant LR Akcinių bendrovių ịstatymo pakeitimus siekta patobulinti bendrovių darbuotojų ir valdymo organų skatinimo institutą. Šio ịstatymo normų pagrindu neatlygintinai ar iš dalies atlygintinai būtų suteikiamos bendrovès akcijos.

Faktiškai ịstatymo projekto rengèjai siekè reglamentuoti akcijų suteikimo bendrovės darbuotojams, valdymo ar priežiūros organų nariams procedūras bei reikalavimus ir taip gerinti reguliavimo lakstumą, plèsti jo taikymo galimybes. Naujas reglamentavimas numate, kad akcijos suteikiamos ne tik darbuotojams, bet ir valdybos ar stebètojų tarybos nariams. Parengtos pataisos priimtos 2017 m. vasarą. Svarbu pastebèti, kad bendrovès akcijos darbuotojui gali būti perduodamos ne tik bendrovès (kaip reguliuoja LR Akcinių bendrovių įstatymas), bet ir akcininko, kaip civilinès apyvartos objektas. Beje, šiuo būdu galima sudaryti ir pasirinkimo sandorị.

Darbuotojų akcijų instituto reglamentavimas tobulintas ne tik įmonių teisès lygmeniu. Akcijų opcionų paramos politika dažniausia siejama ir su palankios mokestinès aplinkos kūrimu ar net mokesčių paskatų numatymu. 2015 m. Lietuvoje veikiančios užsienio kapitalo bankų bendrovès rūpinosi iš patronuojančių bendrovių perkelti darbuotojų motyvavimo schemas ir kẻlè nepalankios mokestinès aplinkos problemą. $2015 \mathrm{~m}$. priimtas Vyriausybès nutarimas, kuriuo numatyta, kad su darbo santykiais susijusioms išmokoms nepriskiriamos pajamos, gaunamos iš akcijų opcionų, jeigu teisè ị akcijas darbuotojams suteikiama ne anksčiau kaip po trejų metų. Taip sumažinta mokestinè našta įmonèms, skatinančioms dalyvauti ar motyvuojančioms darbuotojus akcijų opcionais (Lietuvos Respublikos Vyriausybè, 2015).

Itvirtinti tokị reguliavimą poịstatyminiu teisès aktu nepakako. $2016 \mathrm{~m}$. pavasarị teisèkūros iniciatyvą perėmè LR Seimo Socialinių reikalų ir darbo komitetas. Jo nariai pritarẻ Valstybinio socialinio draudimo ịstatymo projekto pataisoms. Minèti pakeitimai, priimti Seimo, ịsigaliojo 2017 m. pradžioje (Lietuvos Respublikos Vyriausybè, 2017). Tiesa, reikia pastebėti, kad 2018 m. pabaigoje inicijuotas ịstatymo pakeitimas, kuriuo siūlyta vieneriais metais sutrumpinti akcijų išlaikymo terminą (nuo trejų iki dvejų metų), bet šis pakeitimas nepriimtas, o projektas grąžintas tobulinti.

Naujas akcijų opcionų reglamentavimas tik iš dalies išsprendè vadinamają dvigubo apmokestinimo problemą. Pirmiausia, jeigu darbuotojas neišlaiko akcijų trejus metus, jis privalo sumoketi mokesčius (nuo skirtumo tarp akcijų ịsigijimo kainos ir jų rinkos vertès). Vèliau, jeigu akcijų vertẻ bus pakilusi, jas pardavęs darbuotojas privalès dar kartą sumokèti mokesčius nuo vertès skirtumo. İstatymas numatė vieną specifinę schemą - teisè ị akcijas darbuotojams suteikiama ne anksčiau kaip po trejų metų ir neapmokestinama socialinio draudimo įmokomis. 
2017 m. darbuotojų akcijų apmokestinimo klausimas susietas su startuolių verslui palankios aplinkos kūrimu. Problema ta, kad darbuotojui sudarius akcijų opciono sandorị (net ir negavus pajamų), reikejjo iš karto susimokèti mokesčius (nuo skirtumo tarp akcijų ịsigijimo kainos ir jų tikrosios rinkos vertės). Ekonomikos ir inovacijų ministerija inicijavo teisès aktų (Gyventojų pajamų mokesčio įstatymo), nustatančių mokestines lengvatas darbuotojams, kurie pagal akcijų opcionus išlaikè akcijas ilgiau nei trejus metus, pakeitimus (Lietuvos Respublikos ekonomikos ir inovacijų ministerija, 2019). Politikai tikejosi, kad verslą pradedančios įmonès, neturinčios lèšų ir galimybių pasiūlyti darbuotojų poreikius atitinkančių atlyginimų, taip galès darbuotojus pritraukti ar išlaikyti, motyvuoti akcijų opciono pagrindu.

\section{Darbuotojų finansinio dalyvavimo Lietuvoje apimtys ir formos}

Darbuotojų finansinį dalyvavimą Lietuvoje nagrinėję mokslininkai išskyrè šiuos būdingiausius jo bruožus: 1) finansinis dalyvavimas yra gana žemo lygio; 2) Lietuvoje nebuvo paramos politikos, kuri skatintų darbuotojų finansinị dalyvavimą; 3) komplikuoti teisiniai pagrindai (Darškuvienè, Vazniokas, 2006; Lowitzsch, Hashi, 2014; Rimas, 2009; 2010). Kaip parodè R. Civinsko ir J. Dvorak (2017) atliktas tyrimas, padètis po šimtmečio nedaug tepasikeitè. $2016 \mathrm{~m}$. atliktas tyrimas atskleidè, kad pagrindinès darbuotojų finansinio dalyvavimo kliūtys buvo susijusios su nepalankia teisine aplinka, menku darbuotojų investiciniu raštingumu, konservatyvia verslo kultūra ir nepalankia verslo politika, valstybès paramos politikos nebuvimu. Vis dèlto, kaip parodè atliktas tyrimas, 2016-2018 m. pasikeitus teisiniam reglamentavimui, prasidejjo teigiami pokyčiai (Civinskas, Dvorak, 2019).

Remiantis anksčiau atliktais tyrimais galima pastebèti, kad finansinio dalyvavimo apimtys (akcijų nuosavybès forma) Lietuvoje laipsniškai mažèja (išskyrus 2020 m.). Nors Europoje 2019 metais atliktas įmonių tyrimas (European Company Survey) atskleide, kad $39 \%$ ịstaigų vadovų teigimu, bent kai kuriems darbuotojams taikomas kintamasis papildomas atlyginimas, susietas su ịmonès ar įstaigos rezultatais (pelno pasidalijimo schemos), $19 \%$ teigimu, pelno pasidalijimo schema apima mažiausiai $60 \%$ darbuotojų (Houten, Russo, 2020). Pelno pasidalijimas dažniausia taikomas finansinių paslaugų i̇monèse, mažiausiai jis paplitęs statybos sektoriaus įmonèse.

Šiek tiek tikslesnius duomenis pateikè Marc'o Mathieu atliktas tyrimas, kur išnagrinètos didžiausių Europos bendrovių taikomos darbuotojų akcijų programos (Mathieu, 2021). Tyrimui duomenys rinkti 32 Europos Sajungos šalyse, 2723 didžiausiose Europos įmonèse, kuriose dirba 36 milijonai darbuotojų. Šioje ataskaitoje teigiama, kad 2020 m. net $94 \%$ visų didžiųų Europos bendrovių turè- 
DARBUOTOJŲ FINANSINIO DALYVAVIMO LIETUVOJE RAIDA IR FORMOS: İMONIŲ AKCIJŲ... jo darbuotojų akcijų, iš kurių 88 \% turejjo visų rūšių darbuotojų akcijų planus, $53 \%$ - plačiuosius planus, $60 \%$ - akcijų opcionų planus. Kita vertus, ši tendencija pastebima ne visose šalyse (žr. 2 lentelę). Šis tyrimas atskleidè, kad Lietuvoje darbuotojų akcijų programos taikomos vos keliems darbuotojams (situacija pakito tik 2020 m.), visi jie - aukščiausios grandies įmonių vadovai.

2 lentelè. Darbuotojai akcininkai didžiosiose ES kompanijose 2007-2020 metais

\begin{tabular}{|l|l|l|l|l|}
\hline Metai & $\begin{array}{l}\text { Darbuotojai } \\
\text { savininkai } \\
\text { (vienetais) }\end{array}$ & $\begin{array}{l}\text { Procentinis } \\
\text { pokytis }\end{array}$ & $\begin{array}{l}\text { Darbuotojų } \\
\text { savininkų proc. nuo } \\
\text { visų darbuotojų }\end{array}$ & $\begin{array}{l}\text { Darbuotojai } \\
\text { savininkai Lietuvoje } \\
\text { (vienetais) }\end{array}$ \\
\hline 2020 & 7136805 & $+0,5 \%$ & $19,6 \%$ & 378 \\
\hline 2019 & 7098380 & $+3,1 \%$ & $19,6 \%$ & 20 \\
\hline 2018 & 6884482 & $+0,2 \%$ & $19,6 \%$ & 23 \\
\hline 2017 & 6871346 & $+0,6 \%$ & $20,1 \%$ & 28 \\
\hline 2016 & 6827804 & $-0,3 \%$ & $20,2 \%$ & 27 \\
\hline 2015 & 6849325 & $-0,3 \%$ & $20,4 \%$ & 19 \\
\hline 2014 & 6870292 & $-0,6 \%$ & $20,7 \%$ & 17 \\
\hline 2013 & 6908556 & $-4,4 \%$ & $20,8 \%$ & 11 \\
\hline 2012 & 7223183 & $-2,6 \%$ & $22,1 \%$ & 15 \\
\hline 2011 & 7415607 & $+0,0 \%$ & $23,5 \%$ & 14 \\
\hline 2010 & 7412828 & $+2,1 \%$ & $24,0 \%$ & 16 \\
\hline 2009 & 7260926 & $+2,4 \%$ & $23,1 \%$ & 19 \\
\hline 2008 & 7092311 & $+5,4 \%$ & $23,4 \%$ & 24 \\
\hline 2007 & 6731845 & & $23,6 \%$ & 21 \\
\hline
\end{tabular}

Šaltinis: lentelè sudaryta remiantis M. Mathieu (2021) atlikto tyrimo duomenimis.

Be abejo, šis tyrimas dèl specifinès tyrimo imties vertintinas kaip gana selektyvus ir ribotas. Faktiškai jis atskleidžia, kad Lietuvoje veikia nedaug didžiųju korporacijų. Kita vertus, pateikta statistika paaiškina du dalykus: 1) aukščiausio lygmens vadovai, kaip samdomi darbuotojai, taiko akcijų programas; 2) plačiosios darbuotojų įtraukimo programos Lietuvoje nebuvo populiarios. Žinoma, šios išvados, padarytos remiantis ribotu tyrimu, gali būti tolesnio domejjimosi šiais klausimais pagrindas.

Vadovų akcijų opcionai ir jų panaudojimas. Lietuvoje bankų ir finansų sektorių vadovams bei specialistams, dirbantiems su didesnę riziką keliančiais sprendimais, gana dažnai siūlomi akcijų opcionai (kartais vadinami vadovų akcijų opcionais arba vadovaujančių asmenų akcijų opcionais). Tokius siūlymus paprastai teikia tik didžiosios tarptautinès korporacijos, kurios vadovų akcijų opcionų programas į Lietuvoje veikiančius padalinius perkelia specialiai neadaptuotas. Va- 
dovų opcionų programas ịgyvendina ir kelios lietuviško kapitalo įmonès, kurios naudoja ir plačiąsias schemas. Taip jos siekia paskatinti ir nukreipti vadovaujančius asmenis, kaip tinkamai veikiančius iggaliotinius (Rimas, 2010).

Kokybinis tyrimas atskleidè, kad dèl akcijų nuosavybès, kaip skatinimo priemonès veiksmingumo, Lietuvoje veikiančiose įmonėse dažnai diskutuojama. Tyrime dalyvavę vadovų akcijų opcionus taikančių ịmonių atstovai vertino juos dažniausia kaip tinkamas skatinimo priemones. Kita vertus, keli informantai šios priemonès veiksmingumu abejojo. Geriausiai rezervuotą požiūrị i š šias programas atskleidè vienoje skandinavų kapitalo įmonèje vykusi diskusija. Šios įmonès atlyginimo komitete daug diskutuota, ar verta plèsti vadovų akcijų opcionų programą, kuri šiuo metu taikoma labai mažam skaičiui aukščiausio lygmens vadovų. Informantas interviu aptardamas diskusijas dèl jos plètimo pastebejo:

Sunku pasakyti, tikrai sunku pasakyti. Tas labai slidus dalykas su tomis akcijomis yra. (...) Mes irgi turime (...) [paminimas programos pavadinimas] programą. Bet ji yra tik visai top, top menedžmentui. Tai yra jau instrumentas, kuris yra nuleistas iš (...) [paminimas korporacijos pavadinimas] grupès. Mes turime tik laisvę parinkti konkrečius darbuotojus, kurie bus skatinami akcijomis. Jie igyja teises gauti akcijas po trejų metų, kaip ir su atidejjimu. Vadovai gauna akcijų nemokamai. Taip, mes tą irgi turime, tuos akcijų opcionus. Tai va. Mums dabar aktualu kita. Šiuo metu mes siekiame atnaujinti kintamujų atlyginimo dalių ir naudų sistemas. Taip vis siekiame, ieškome naujų būdų, kaip motyvuoti (...) Tai ir mūsų metinis priedas yra kaip ir under discussion. Apie tas akcijas. Tai mes diskutavome apie minètos programos išplètimą kitiems vadovams. Bet žinote, gal dar mes esame nepasiruošę įvedinèti tai. Tai gali būti nepatrauklu (interviu su INF12).

Šis interviu atskleidžia, kad įmone nedrịso taikyti išplèsto ilgalaikio skatinimo vadovams programos (visoje korporacijoje ji taikoma tik keliems šimtams darbuotojų) dèl kelių priežasčių: 1) galimo nepriimtinumo; 2) veiksmingo skatinimo kitomis kintamo atlygio sistemos dalimis ir naudų priemonėmis; 3) šioje įmonéje vidutinès grandies vadovai nepriima didesnę riziką keliančių sprendimų. Pastebėtina, kad ši programa sudaryta pagal pasiekimų opcionų (angl. performance vested) schemą. Tiksliau, akcijos teikiamos su sąlyga, kad bus pasiekti iškelti įmonès tikslai.

2014-2017 m. programoje dalyvavo 103 grupès dalyviai. Jiems suteikta akcijų nuosavybė siekė vidutiniškai 4,2 proc. Šis opcionas vertintas, atsižvelgiant ị padalinių tikslų pasiekiamumą. Vertinta pagal du pagrindinius veiklos rodiklius: bendrą akcijų grąžą ir pelną prieš palūkanas, mokesčius, nusidèvẻjimą bei amortizaciją (angl. Earnings Before Interest, Taxes, Depreciation and Amortization - EBITDA) pelningumo koeficiento pagrindu. İdomu tai, kad vienas iš veiklos rodiklių žymèjo dukterinès įmonès vietos kaitumą korporacijos vidaus reitinguose. Panašias pro- 
gramas savo dukterinėse įmonėse taiko ir tokios korporacijos kaip ASA „Orkla“ (angl. Management option programme), AB „Swedbank Group“ (angl. Individual Program 2019, IP 2019), AB „SEB Group“ (angl. Restricted Share Programme 2019).

Kiek kitokį darbuotojų akcijų teikimo planą pasiūlè AB „Linas Agro Group“. Jos pavaldžiosiose įmonėse $2018 \mathrm{~m}$. dirbo 2199 darbuotojai, iš kurių 133 buvo vadovai. Ši įmonè, vykdydama akcijų opcionų planą, siekè įtraukti įmonès grupès darbuotojus ir organų narius ị dalyvavimą bendrovès kapitale (AB „Linas Agro Group “, 2020). Bendrovès akcijų teikimo planas turejo veikti kaip papildoma motyvaciné priemonè. $2018 \mathrm{~m}$. patvirtintose akcijų teikimo taisyklèse numatyta sąlyga, kad akcijos suteikiamos darbuotojams, kurie toje įmonejje yra išdirbę ne mažiau kaip 20 metų. 2018 m. birželio 1 d. visuotinio akcininkų susirinkimo sprendimu, opcionų sutartys sudarytos su akcinès bendrovès AB „Linas Agro Group“ ir pavaldžių įmonių darbuotojais. Ne mažiau kaip po trejų metų opcionų sutartyse nustatyta tvarka šie darbuotojai ịis teisę ị akcijas. Akcijos suteiktos neatlygintinai (AB „Linas Agro Group“ pasirašè akcijų opcionų sutartis su darbuotojais, 2018).

Atliekant tyrimą patikslinta, kad akcijos suteiktos daugiausia vadovaujantiems asmenims. Deja, nepavyko gauti tikslių duomenų apie vadovų ir kitų darbuotojų įtraukimą ị akcijų opcionų planą. Ši akcijų opciono sutartis buvo tarsi vadovų ir kitų darbuotojų apdovanojimas už nuopelnus. Akcijų opcionų planas tiesiogiai nesusietas su pelno paskirstymu, kaip aptarta anksčiau. Vis dèlto grupei priklausančiu įmonių 2018 m. veikla buvo pelninga (Čiulada, 2019). Svarbu pastebėti, kad šis akcijų opcionų planas numatè ir modifikuotus (3-5 metų) atidejjimo laikotarpius. Matyt, tokia akcijų opcionų sutarčiu atidẻjimo sąlyga galëjo ilgiau išlaikyti tam tikrus darbuotojus.

Akcijų dovanojimo programos, jų veiksmingumas. Kartais Lietuvos atvirojo ar uždarojo tipo akcinių bendrovių vadovai dovanoja ar parduoda už simbolinę kainą akcijų. Remiantis teisès įmonių atstovų pateikta informacija, galima nuspèti, kad ši schema yra paprastesnè už tas, kur akcijas perduoda bendrovè. Tai lemia kelios priežastys: 1) greitesnis praktinis pasirinktos schemos pritaikymas; 2) tai yra priimtiniau mokestiniu aspektu. Akcijos apmokestinamos tik gyventoju pajamų mokesčiu ir nereikia laukti trejų metų atidejjimo dẻl mokestinių lengvatų (socialinio draudimo ir privalomojo sveikatos draudimo). Apskritai akcijų opciono schema būtų greitai ịgyvendinama ir tam neprireiktų sudètingų administravimo struktūrų. Tačiau pagal šią schemą sudarant teisinị sandorị būtinas tam tikras sandorio ir notarinių formų atitikimas. Tokios schemos pasirinkimas patrauklus, kai įmonès akcijų paketą turi vienas ar keli savininkai (jeigu keli, tarp jų būtinas sutarimas). 
Ypač čia svarbus pasitikejjimas ir akcininkų vertybes atliepianti organizacijos kultūra. Tai patvirtino keli interviu duomenys (interviu su INF13; INF14). Faktiškai Lietuvoje šias akcijų dovanojimo ar pardavimo (dažniausia už simbolinę kainą) sutartis taiko ne tik atvirojo, bet ir uždarojo tipo bendrovès. Svarbu pastebėti, kad praktiškai veikia du akcijų perdavimo būdai, atsižvelgiant ị ịmonių tikslus: 1) jų dovanojimas darbuotojams (paprastai nusipelniusiems) įtvirtinant įmonės vertybes ir motyvuojant ar siekiant išlaikyti juos organizacijoje; 2) pasidalijimas verslu su nusipelniusiais darbuotojais (paprastai vadovaujančiais).

Kokybinio tyrimo analizè atskleidè, kad dovanojant akcijas siekiama ịtvirtinti norimą kultūrą (tai siejama su tam tikromis vertybėmis, pagrindinių akcininkų, kartu ir vadovų stiliumi, tarnauja kaip kultūros elementų sustiprinimo priemoné, pavyzdžiui, akcijų dovanojimas ịgyja simbolinę prasmę, tai siejant su įmonès ar savininkų jubiliejais, svarbiais organizaciniais pokyčiais). İdomu yra tai, kad informantas reflektavo pasirinkimus iš trijų schemų: akcininkai dovanoja akcijas, ịmoné dovanoja akcijas ir akcininkų opcionai. Pasirikimo procesą jis apibūdino jị detalizuodamas:

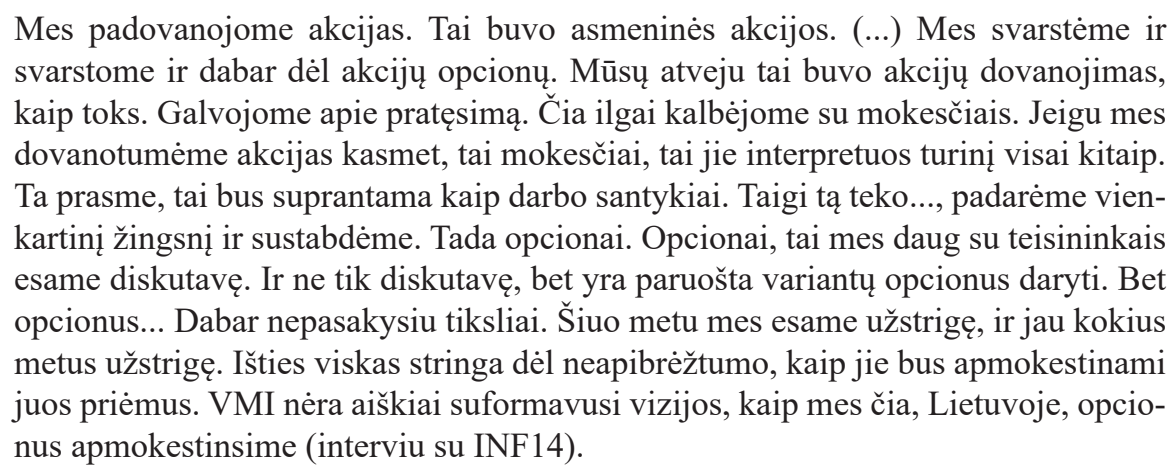

Ši citata atskleidžia, kad informantui (jis yra ir vienas iš dviejų pagrindinių akcininkų) akcijų dovanojimas buvo priimtiniausias, siekiant reikšmingai atsidèkoti už ilgus bendro darbo metus (tai suprasta kaip vienkartinè priemonè, sieta su įmonès veiklos jubiliejumi, grupe itin nusipelniusių darbuotojų, dideliu pasitikejjimu jiems, taigi akcijų suteikimas buvo padèkos išraiška). Kita vertus, įmonès savininkai mąstė ir apie šios priemonès galimą tęstinumą. Žinoma, svarbiausias veiksnys, nulèmęs šios schemos pasirinkimą, yra palanki mokestiné aplinka. İdomu tai, kad neaiškumai dèl apmokestinimo neleido įmonei tvirtinti akcijų opcionų programos, nors tam ji buvo pasiruošusi.

Darbuotojų akcijų pardavimas už simbolinę kainą yra kita įmonių dažnai taikoma schema. Tai būdas pasidalinti verslą su to nusipelniusiais ir verslo tęstinumui svarbiais darbuotojais. Tai iliustruoja UAB „Ad Rem Transport“ atvejis, kai jos di- 
rektorius ir pagrindinis akcininkas $2019 \mathrm{~m}$. trečdalị akcijų perdavė dviem kitiems vadovams. Atrodo, kad tai lẻmė ne tik siekis išlaikyti vadovaujančius darbuotojus, bet ir įmonès kultūra (Miknevičius, 2019; Stamkauskienè, 2018).

Akcijų opcionų programos startuolių įmonèse. Kokybinis tyrimas atskleidè, kad Lietuvoje startuolių ịmonès dažniausia taiko ar ruošiasi taikyti akcijų opcionų programas. Nors kokybinio tyrimo apribojimai neleido atskleisti taikomų schemų ịvairovès, dominuojančius bruožus leido apčiuopti. Tai pavyko, nes savo apibendrinančiomis įžvalgomis dalijosi gerai opcionų taikymą startuolių ekosistemoje išmanantis informantas. Jis atskleide įmonejje taikomus akcijų nuosavybès programos turinio elementus ir palygino juos su taikomais kituose startuoliuose. Informantas pastebejo, kad jų įmonèje taikoma plačioji programa (taikoma visiems, o ne išskirtiniams darbuotojams - programuotojams, sistemų analitikams, programinès įrangos architektams ar pan.). Ją paskatino taikyti vadovų asmeninės nuostatos ir verslo filosofija:

Vadovai, mes patys jį nusprendžiame. Prièmėme sprendimą, kad opcionus duosim absoliučiai visiems (nuo 2013 metų), kada pradèjome rimčiau dirbti. Ta filosofija atèjo iš pačių savininkų ir ta filosofija yra išlaikoma iki šiol. Tas sprendimas buvo labai paprastas ir vienareikšmis. Mes niekada neabejojome šiuo sprendimu. Manau, kad taikysime tai ir toliau. Tai yra verslo filosofija. Jeigu tu manai, kad žmonés, kuriuos tu samdai, nesukuria vertes ir jiems nereikia duoti opcionų, tada kam apskritai tuos žmones samdai? Pas mus dirbantys žmonès pagal mūsų filosofiją visi kuria vertę. Vienareikšmiškai jie visi kuria vertę, užimdami skirtingas pareigas ir dirbdami skirtingose srityse. Aišku, galima aiškinti, kad stiprus ir daug patirties turintis programuotojas sukuria daugiau vertès nei administratorius. Objektyviai atlyginimą pagal nuopelnus gali padaryti per dalijamų opcionų kiekius. Bet administratorius taip pat sukuria daug nematomos vertès, todèl jis taip pat gali siekti gauti didelị opcionų kiekị (interviu su INF17).

Informantas atskleidè, kad įmonėse programų parengimas dažniausia priklauso nuo vadovų nuostatų ir tikslų. Be to, akcentavo, kad kažkiek ịtakos gali turèti ir rizikos fondų valdytojai, kurie su siūloma investicija atsineša ir taikomų opcionų modelius. Jis pastebejjo, kad darbuotojų akcijų opcionų taikymo idejjas ir programas gali atsinešti ir padalinius Lietuvoje kuriančios startuolių bendrovès. Nagrinèjama ịmonè akcijų opcionų programą taiko septynerius metus. Jos akcijų įsigijimo atidejjimo terminas yra net dešimt metų. Tai išties netipiška. Informantas tai akcentuoja ir lygindamas pastebi, kad startuoliai JAV ir Lietuvoje taiko skirtingus akciju ịsigijimo momentus:

Pas mus yra akcijų opcionai yra dešimt metų. Tačiau ị mūsų praktiką nereikètų žiūrèti kaip ị pavyzdį, kadangi tai - ganètinai unikalu. Mes prièmeme tokị sprendimą, kuris 
yra labiau motyvuojantis darbuotojus. Esmè ta, kad opcionų nereikia išsipirkti labai staigiai. JAV būna nuo kelių mẻnesių iki metų dažniausiai. Laikotarpiai gana trumpi.

(...) Dvejų trejų metų laikotarpiai yra tikrai geras variantas (interviu su INF17).

Labiausiai komplikuotas informantui atrodo akcijų atpirkimo mechanizmas. Tai ypač aktualu panašias schemas taikančioms uždarosioms akcinėms bendrovėms. Schemoje turi būti numatytas ir suderintas akcijų atpirkimas, kad darbuotojai realiai galètų igytas akcijas parduoti (Kahle, 2002). Žinoma, darbuotojų akcijų vertè, jo manymu, gali staigiai pakilti ịmonę pardavus:

...Kol nepavyks darbuotojams tuos opcionus išsikašinti [išsigryninti], tol tokio didelio exito [išèjimo] nèra. Kol jis vienas, du, trys neịvyks, tol sistema, tie opcionai nevažiuos ir jie nebus taip stipriai vertinami. (...) Listinguojamos kompanijos jau yra pasirengusios, priejjusios iki tokio lygio, kad geba listinguoti savo akcijas sèkmingai ir tomis akcijomis birža prekiauja. Tai dažniausiai nebūna ankstyvos kompanijos vystymosi fazès. Tai būna ganètinai gerą lygị pasiekusios pardavimuose, turinčios pelningumą kompanijos. Tokiu atveju vyrauja visiškai kitokia dinamika. Listinguojamose kompanijose darbuotojas, kai ateina ir gauna akcijas, nesitiki (arba tikisi kur kas mažiau), kad jo akcijų vertè augs eksponentiškai. Startupe, mažoje technologineje kompanijoje, kuri tik pradeda augti, 20-50 kartų nuo pat atsidarymo pradžios. Visi ir turi tokị lūkestị, kad išaugs labai stipriai. Tas ir yra, kad listinguojamoje kompanijoje padidinus akcijų vertę du kartus yra labai didelis pasiekimas (interviu su INF19).

Informantas nurodė, kad vienas didžiausių startuolių UAB „Vinted“ iš darbuotojų kelis kartus išpirko akcijas. Pastebètina, kad galimai ši įmonè taiko plačiąsias schemas (Baltrušaitytè, 2015). Be to, šias akcijų opcionų programas inicijuoja ne tik gana aukštą brandos lygị pasiekę startuoliai, bet ir nedidelès įmonès. Pavyzdžiui, tarptautiniu mastu veikiančios įmonès „DappRadar“ atstovas Ian'as Kane, duodamas interviu „15min.lt“, paaiškino įmonès sprendimą dèl akcijų opcionų taikymo: „Idejja siūlyti darbuotojams lengvatinèmis sąlygomis įsigyti įmonės akcijų - paprasta. Lietuva kyla ir vystosi, todèl pasiūlome savo darbuotojams dar vieną priežastị čia likti ir dirbti. Be to, turime ilgalaikę veiklos strategiją šioje šalyje. Norime investuoti ị savo darbuotojus ir kad jie taip pat gautų vertès iš savo sunkaus darbo. Be to, norime pritraukti ryškiausius savo srities talentus“ (Motyvacinė priemonè, kurios vertę supranta ne visi - vertè gali užaugti penkiagubai, 2019).

Kita vertus, iš interviu aiškejja, kad įmone dar tik aiškinasi šios motyvavimo ir skatinimo priemonès veiksmingumą ir planuoja galutinai apsispręsti dẻl darbuotojų akcijų programos per ateinančius metus. Interviu atskleidžia, kad diegti tokią programą skatina vienas iš kompanijos atstovų, turintis dalyvavimo panašiose programose patirties. 


\section{Darbuotojų finansinio dalyvavimo Lietuvoje raidos galimybès}

Plačios darbuotojų akcijų opcionų programos skandinaviško ir lietuviško kapitalo bendrovėse dažniausia taikomos. Dokumentinė analizė atskleide, kad keturios iš penkių nagrinètų programų yra vadinamosios pelno padalijimo programos, o viena ịmonè siūlo darbuotojams ịsigyti ịmonių grupès akcijų su nuolaida. Akcijų padalijimo programa turi schemą, kuri dar vadinama pirkimo opcionu (angl. call option). Daugelis programose įtvirtintų schemų (pelno paskirstymas darbuotojų akcijoms) yra panašios struktūros. Jose kintamojo atlygio priemoka nuo pelno dažniausia skiriama akcijoms įsigyti, jeigu darbuotojas atitinka dalyvavimo programoje sąlygas ir sutinka dalyvauti.

Atlikus programų tikslų analizę paaiškejo, kad dauguma jų nukreipti ị darbuotojų motyvavimą, ịtraukimą ir skatinimą. Kelios Lietuvos įmonès siekia taikomomis programomis suderinti akcininkų ir darbuotojų interesus. Programų tikslai ir prioritetai paaiškina tik programos kontūrus. Visumos vaizdas gali būti sudèliotas apibrěžiant kai kuriuos svarbius turinio (programos schemos) ir taikymo elementus. Absoliučiaisiais skaičiais daugiausia darbuotojų dalyvauja AB „Swedbank“ įmonejje vykdomoje programoje. Tikètina, kad šios įmonès programose dalyvauja maždaug 1000-1500 darbuotojų. Nemažai darbuotojų i savo vykdomą programą ịtraukè ir AB „Klaipèdos nafta“.

Atlikus akcijų opcionų taisyklių ir kitų ịmonių dokumentų analizę paaiškejjo, kad: 1) dažniausia ị sąlygų rengimą, derinimą ir tvirtinimą ịtraukiami pagrindiniai bendrovių organai (taisyklių ịgyvendinimą ir sutarčių pasirašymo administravimą vykdo tam paskirti įmonių struktūriniai padaliniai); 2) atnaujinant programą ar inicijuojant naują vertinama, ar pasiekti veiklos rezultatų tikslai ir kiek už jų pasiekimą konkrečiam darbuotojui galima suteikti akcijų; 3) priimami sprendimai dèl programos tvirtinimo ar atnaujinimo (numatoma akcijų klasė ir nominalioji verte்); 4) bendrovejje suformuojamas akcijų rezervas (emisija); 5) rengiamas darbuotojo opciono projektas, kuris vẻliau tvirtinamas atsakingų valdymo organų; 6) asmenų, galinčių dalyvauti, išskyrimas; 7) darbuotojų informavimas, sutarčių sudarymas.

Vadovų akcijų opcionų programomis ar priemonèmis siekiama ne tik paskatinti vadovus, kaip igaliotinius, bet ir suderinti akcininkų bei aukščiausio lygmens vadovų interesus, spręsti rizikos vengimo (angl. risk aversion) problemas. Agentūros teorija aiškina, kad vadovai, veikdami kaip ịgaliotiniai, skatinami priimti rizikingus sprendimus (Jensen, Meckling, 1976). Manoma, kad rizikingi sprendimai teigiamai paveiks ir jų akcijų nuosavybę. Šiuo atveju remiamasi prielaida, kad vadovai, skirtingai nei akcininkai, labiau linkę vengti rizikingų sprendimų (Eisenhardt, 1989). 
Agentūros elgsenos modelio teorija besiremiantys mokslininkai aiškina, kad akcijų nuosavybė vadovų elgsenos nekeičia. Tai pagrịsta ir empirinių tyrimų pagrindu gautomis išvadomis. Daugeliu atvejų įrodyta, kad akcijų opcionų išdavimas skatina rizikos vengimo elgseną ir neigiamai veikia vadovų priimamus sprendimus (Martin ir kt., 2013; Sanders, Hambrick, 2007). Mokslinès diskusijos pakrypo i mišraus lošimo (angl. mixed gamble) sukuriamą akcijų nuosavybès suteikimo poveikị. Tai reiškia, kad akcijų opcionų suteikimas vadovams gali būti naudingas arba nenaudingas, t. y. iggaliotiniai neužtikrintumo situacijose gali elgtis orientuodamiesi ị akcininkų interesus (priimami rizikingesni sprendimai) arba savanaudiškai (vengiama rizikos).

Suprantama, vienas ar kitas veikimas gali nulemti teigiamus arba neigiamus sprendimus. Empiriniai tyrimai tik pagrindžia, kad akcijų opcionų mechanizmai turi įtakos vadovų elgsenai (Lim, Mccann, 2013; Triki, Ureche-Rangau, 2012; Zona, 2016). Kartu aptarta mokslinè diskusija ir tyrimų rezultatai atskleidžia, kad vadovų akcijų opcionai nebūtinai sukuria gerai veikiančias vadovų skatinimo ir elgesio nukreipimo (ar derinimo su akcininkų interesais) sistemas. Tikètina, kad tai yra viena iš priežasčių, kodèl vadovų akcijų opcionai netaikomi taip plačiai, kaip galètų.

Lietuvos atvirojo ar uždarojo tipo akcinių bendrovių vadovai įmonès darbuotojams dovanoja akcijas kaip privatūs asmenys. Taip siekiama ịtvirtinti atitinkamą organizacijos vertybių kultūrą. Akcijų dovanojimo arba perdavimo už simbolinę kainą schemos yra alternatyvios akcijų opcionams ir tam tikrais atvejais, atsižvelgiant ị ịmonių tikslus, gali būti priimtinos. Jos dažniausia siejamos su verslo dalies perdavimu nusipelniusiems vadovams ar nusipelniusių darbuotojų motyvavimu, organizacinès kultūros stiprinimu. Pagrindinis darbuotojų akcijų planų trūkumas susijęs su tęstinio taikymo apribojimais, kurie nulemti neaiškumų mokestinèje aplinkoje.

Akcijų opcionų programas Lietuvoje taiko arba ruošiasi tai daryti startuolių imonès. Dalis jų taiko plačiąsias schemas, kitos renkasi siauresnes. Šiose įmonèse taikomos netipiškos finansinio dalyvavimo schemos. Joms poveikị daro ir rizikos fondų valdytojai, su siūloma investicija atsinešantys ir taikomų opcionų modelius. Startuolių įmonei sudėtingiausia numatyti akcijų atpirkimo procesą, kad darbuotojai iggytas akcijas galètų parduoti.

\section{Išvados}

1. Lietuvoje darbuotojų finansinio dalyvavimo paramos politika pradèta igyvendinti prieš penketą metų. Ja siekta esamą reglamentavimą išplèsti, atsižvelgiant ị verslo ịmonių poreikius. Keičiant esamą mokestinį reguliavimą 
kurta ir akcijų opcionų taikymui palankesnè mokestinė aplinka. Šios politikos rezultatai nebuvo pakankamai veiksmingi. Pirmiausia teisinis reglamentavimas yra gana painus ir nuolat kito. Neaiškus liko darbuotojams suteiktų akcijų apmokestinimas ir praktinis mokesčių lengvatų taikymas.

2. Lietuvoje dažniausia taikomos keturios darbuotojų akcijų nuosavybės programos ir planai: plačiosios darbuotojų akcijų opcionų programos; darbuotojų akcijų opcionų skyrimas vadovams; akcijų opcionų programos startuolių įmonėse; akcininkų darbuotojams teikiamos akcijos.

3. Nustatyta, kad instituciniai veiksniai ir skatina, ir riboja finansinio dalyvavimo instrumentų taikymą Lietuvoje. Valdžios išplèstas teisinis reguliavimas ir palankesnis akcijų opcionų apmokestinimas paskatino įmones vykdyti darbuotojų akcijų nuosavybės programas. Teigiamą poveikị Lietuvoje turèjo tarptautinių korporacijų sprendimas ị Lietuvą perkelti kituose organizacijų padaliniuose jau veikiančias akcijų opcionų programas. Taip skleidžiami gerosios patirties pavydžiai, teigiamai veikiantys darbuotojų finansinio dalyvavimo Lietuvoje pletrą. Akcijų opcionų programos startuolių įmonèse Lietuvoje turètų teigiamai paveikti ir inovacijų plètrą. Darbuotojų finansinio dalyvavimo raidą Lietuvoje stabdo menkas žmonių finansinis raštingumas ir maža vertybinių popierių rinka.

\section{Literatūra}

AB „Linas Agro Group “ pasirašè akciju opcionu sutartis su darbuotojais. (2018). Linasagro.Lt. Prieiga internete: https://www.linasagro.lt/naujienos/ab-linas-agro-group-pasirase-akciju-opcionu-sutartis-su-darbuotojais

AB „Linas Agro Group“. (2020). AB „Linas Agro Group “ akciju suteikimo taisyklès. Prieiga internete: https:// www.linasagrogroup.1t/wp-content/uploads/2013/02/LNA_Akciju_suteikimo_taisykles_Rules_for_Shares Issue.pdf

Aubert, N., Kern, A., \& Hollandts, X. (2017). Employee stock ownership and the cost of capital. Research in International Business and Finance, Vol. 41, p. 67-78.

Baixauli-Soler, J. S., Belda-Ruiz, M., \& Sanchez-Marin, G. (2015). Executive stock options, gender diversity in the top management team, and firm risk taking. Journal of Business Research, Vol. 68(2), p. 451-463.

Baltrušaitytė, M. (2015). Jeigu jiems pavyks - įkvèps tūkstančius. Delfi, vasario 22. Prieiga internete: https:// www.delfi.lt/verslas/verslas/jeigu-jiems-pavyks-ikveps-tukstancius.d?id=67083138

Brandes, P., Dharwadkar, R., \& Lemesis, G. V. (2003). Effective employee stock option design: Reconciling stakeholder, strategic, and motivational factors. Academy of Management Perspectives, Vol. 17(1), p. 77-93.

Bryson, A., Freeman, R., Lucifora, C., Pellizzari, M., \& Perotin, V. (2012). Paying for performance: incentive pay schemes and employees' financial participation. Centre for Economic Performance, LSE.

Cassell, C., \& Bishop, V. (2019). Qualitative data analysis: Exploring themes, metaphors and stories. European Management Review, Vol. 16(1), p. 195-207.

Čiulada, P. (2019). „Linas Agro Group“ mirksta nuostoliuose: grūdus parduoda pigiau nei perka. Verslo žinios. Prieiga internete: https://www.vz.lt/rinkos/2019/08/30/linas-agro-group-mirksta-nuostoliuose-grudusparduoda-pigiau

Civinskas, R., \& Dvorak, J. (2017). New social cooperation model in service oriented economy: the case of employee financial participation in the Baltic states. Engineering Management in Production and Services, Vol. 9(3), p. 37-55. 


\section{Remigijus Civinskas, Rimantas Stašys}

Civinskas, R., \& Dvorak, J. (2019). In search of employee perspective: understanding how Lithuanian companies use employees representatives in the adoption of company's decisions. Administrative Sciences, Vol. 9(4), p. 78.

Damiani, M. (2009). The Stakeholder Corporate Governance View Revisited. Corporate Governance, Organization and the Firm, Edward Elgar, Cheltenham and Northampton, p. 19-47.

Darškuvienè, V., \& Vazniokas, P. (2006). Stock ownership as a form of employee and management financial participation: factors of development in Lithuania. Management of Organizations: Systematic Research, Vol. 38, p. 57-74.

Eisenhardt, K. M. (1989). Agency theory: An assessment and review. Academy of Management Review, Vol. 14(1), p. 57-74.

Elouadi, S., Noamene, T. Ben, \& Chaher, D. (2016). Employee ownership and employee-shareholders satisfaction: An analysis of French companies listed on the sbf 250. Journal of Applied Business Research (JABR), Vol. 32(3), p. 981-994.

Faleye, O., Mehrotra, V., Morck, R. (2006). When labor has a voice in corporate governance. Journal of Financial and Quantitative Analysis, Vol. 41(3), 489-510.

Fama, E. F., \& Jensen, M. C. (1983). Separation of ownership and control. The Journal of Law and Economics, Vol. 26(2), p. 301-325.

Freeman, R. B., Blasi, J. R., \& Kruse, D. L. (2009). Shared Capitalism: at Work: Employee Ownership, Profit and Gain Sharing, and Broad-based Stock Options. Chicago: University of Chicago Press.

Freeman, R. E., Harrison, J. S., Wicks, A. C., Parmar, B. L., \& De Colle, S. (2010). Stakeholder Theory. The State of the Art. Cambridge University Press: Cambridge.

Freeman, R. E. (2010). Strategic management: A stakeholder approach. Cambridge University Press.

Geczy, C., Jeffers, J. S., Musto, D. K., \& Tucker, A. M. (2016). In pursuit of good \& gold: Data observations of employee ownership \& impact investment. Seattle University Law Review, Vol. 40, p. 555-610.

Guedri, Z., \& Hollandts, X. (2008). Beyond dichotomy: The curvilinear impact of employee ownership on firm performance. Corporate Governance: An International Review, Vol. 16(5), p. 460-474.

Houten, G. van, \& Russo, G. (2020). European Company Survey 2019: Workplace Practices Unlocking Employee Potential. Publications Office of the European Union: Luxembourg.

Jaffee, J., \& Freeman, J. (2000). Institutional change in real-time: The development of employee stock options for German venture capital. The New Institutionalism in Strategic Management. Emerald Group Publishing Limited.

Jensen, M. C., \& Meckling, W. H. (1976). Theory of the firm: Managerial behavior, agency costs and ownership structure. Journal of Financial Economics, Vol. 3(4), p. 305-360.

Jones, D. C., \& Mygind, N. (2000). The effects of privatization on productive efficiency: evidence from the Baltic Republics. Annals of Public and Cooperative Economics, Vol. 71(3), p. 415-439.

Kahle, K. M. (2002). When a buyback isn'ta buyback: Open market repurchases and employee options. Journal of Financial Economics, Vol. 63(2), p. 235-261.

Kang, S., \& Kim, A. (2019). Employee stock ownership and financial performance in European countries: The moderating effects of uncertainty avoidance and social trust. Human Resource Management, Vol. 58(6), p. $641-655$.

Kim, K. Y., \& Patel, P. C. (2017). Employee ownership and firm performance: A variance decomposition analysis of European firms. Journal of Business Research, Vol. 70, p. 248-254.

Kroumova, M. K., \& Sesil, J. C. (2006). Intellectual capital, monitoring, and risk: what predicts the adoption of employee stock options? Industrial Relations: A Journal of Economy and Society, Vol. 45(4), p. 734-752.

Kurtulus, F. A., \& Kruse, D. (2018). An empirical analysis of the relationship between employee ownership and employment stability in the US: 1999-2011. British Journal of Industrial Relations, Vol. 56(2), p. $245-291$.

Lamberg, J., Savage, G. T., \& Pajunen, K. (2003). Strategic stakeholder perspective to ESOP negotiations: the case of United Airlines. Decision, Vol. 44, p. 383-393.

Lietuvos Respublikos akciniu bendroviu įstatymo Nr. VIII-1835 2, 15, 20, 28, 32, 34, 37, 38, 45, 46, 47, 51, 52, 54, 57 ir 59 straipsniu pakeitimo ir istatymo papildymo 471 ir 472 straipsniais įstatymo projekto aiškinamasis raštas. (n.d.). Prieiga internete: https://e-seimas.lrs.lt/rs/lasupplement/TAP/360917d0aed911e59010bea026b db259/cc237458aed911e59010bea026bdb259/format/ISO_PDF

Gyventojų pajamų mokesčio ịstatymo Nr. IX-1007 17 straipsnio pakeitimo ịstatymo projekto, Nr. XIIIP-3388. Prieiga internete: https://e-seimas.1rs.lt/portal/legalAct/lt/TAK/99f38f4060d411e99684a7f33a9827ac?jfwi $\underline{\mathrm{d}=12 \mathrm{mhdvi} \text { zp\&fbclid=IwAR0uAR5tKi373cW6IlFAYNON_RMf8GsDsTTAjEgJiUtHptXZoi3mktIBon0 }}$ 


\section{DARBUOTOJŲ FINANSINIO DALYVAVIMO LIETUVOJE RAIDA IR FORMOS: İMONIŲ AKCIJŲ...}

Lietuvos Respublikos Vyriausybė. (2015). Dèl Lietuvos Respublikos Vyriausybès 2005 m. birželio 14 d. nutarimo Nr. 647 „Dèl Lietuvos Respublikos valstybinio socialinio draudimo fondo biudžeto sudarymo ir vykdymo taisykliu patvirtinimo " pakeitimo. Prieiga internete: https://e-seimas.1rs.1t/portal/legalAct/1t/TAD/34d92590a e2411e59010bea026bdb259?jfwid=bkaxn7j0

Lietuvos Respublikos Vyriausybè. (2017). Lietuvos Respublikos valstybinio socialinio draudimo istatymo Nr. I-1336 2, 3, 8, 10, 11, 12, 13, 19, 25, 35 ir 40 straipsniu pakeitimo istatymas. Prieiga internete: https://eseimas.lrs.lt/portal/legalAct/lt/TAP/17edcf50cde711e782d4fd2c44cc67af

Lim, E. N. K., \& Mccann, B. T. (2013). The influence of relative values of outside director stock options on firm strategic risk from a multiagent perspective. Strategic Management Journal, Vol. 34(13), p. 1568-1590.

Lowitzsch, J. (2009). Financial Participation of Employees in the EU-27. Springer.

Lowitzsch, J., Dunsch, S., Hashi, I., EU, A. P. N., \& Market, A. L. (2017). Spanish Sociedades Laborales Activating the Unemployed. A Potential New EU Active Labour Market Policy Instrument.

Lowitzsch, J., \& Hashi, I. (2014). The promotion of employee ownership and participation. Study prepared by the Inter-University Centrefor European Commission's DG MARKT.

PrMartin, G. P., Gomez-Mejia, L. R., \& Wiseman, R. M. (2013). Executive stock options as mixed gambles: Revisiting the behavioral agency model. Academy of Management Journal, Vol. 56(2), p. 451-472.

Mathieu, M. (2021). Annual economic survey of employee share ownership in European countries. European Federation of Employee Share Ownership. Prieiga internete: http://www.efesonline.org/Annual\%20 Economic\%20Survey/2020/Survey\%202020.pdf.

Miknevičius, L. (2019). „Ad Rem“ grupé vadovus „prisirišo“ įmonės akcijomis. Verslo žinios. Prieiga internete: https://www.vz.lt/transportas-logistika/2019/02/05/ad-rem-grupe-vadovus-prisiriso-imones-akcijomis

Motyvacinė priemonè, kurios vertę supranta ne visi - vertė gali užaugti penkiagubai. (2019). 15min.Lt. Prieiga internete: https://www.15min.lt/verslas/naujiena/karjera/cvbankas-lt-motyvacine-priemone-kurios-vertesupranta-ne-visi-verte-gali-uzaugti-penkiagubai-666-1245276

Mygind, N. (1997). Privatisation and employee ownership: the development in the Baltic countries. Transition in the Baltic States, p. 131-147. Springer.

Mygind, N. (2012). Trends in employee ownership in Eastern Europe. The International Journal of Human Resource Management, Vol. 23(8), p. 1611-1642.

Poutsma, E., \& Kaarsemaker, E. (2015). Added value of employee financial participation. Human Resource Management Practices, p. 181-196. Springer.

Poutsma, E., Ligthart, P. E. M., \& Kaarsemaker, E. C. A. (2017). Employee ownership and high-performance work systems in context. Sharing in the Company. Emerald Publishing Limited.

Renneboog, L., Ter Horst, J., \& Zhang, C. (2008). The price of ethics and stakeholder governance: The performance of socially responsible mutual funds. Journal of Corporate Finance, Vol. 14(3), p. 302-322.

Reynolds, J. (2014). Sharing Profits: The ethics of remuneration, tax and shareholder returns. Springer.

Richter, A., \& Schrader, S. (2017). Levels of employee share ownership and the performance of listed companies in Europe. British Journal of Industrial Relations, Vol. 55(2), p. 396-420.

Rimas, J. (2009). Akcijų opcionai kaip privataus kapitalo investuotojo ir bendrovès vadovų interesų derinimo priemonè. Teise, Vol. 73, p. 124-135.

Rimas, J. (2010). Privataus kapitalo sandoriai-bendroviu teisès aspektai. Daktaro disertacija. Vilniaus universitetas, p.1-336.

Sahakiants, I., \& Festing, M. (2019). The use of executive share-based compensation in Poland: Investigating institutional and agency-based determinants in an emerging market. The International Journal of Human Resource Management, Vol. 30(6), p. 1036-1057.

Sanders, W. G., \& Hambrick, D. C. (2007). Swinging for the fences: The effects of CEO stock options on company risk taking and performance. Academy of Management Journal, Vol. 50(5), p. 1055-1078.

Shipper, F. (2014). Shared entrepreneurship: A path to engaged employee ownership. Springer.

Stamkauskienė, R. (2018). Kompanija, kurioje galioja džentelmenų kodeksas. Verslo žinios. Prieiga internete: https://www.vz.lt/transportas-logistika/2018/09/18/kompanija-kurioje-galioja-dzentelmenu-kodeksas

Thompson, P. B., McWilliams, A., \& Shanley, M. (2014). Creating competitive advantage: a stakeholder view of employee ownership. International Journal of Strategic Change Management, Vol. 5(3), p. 262-279.

Triki, T., \& Ureche-Rangau, L. (2012). Stock options and firm performance: New evidence from the French market. Journal of International Financial Management \& Accounting, Vol. 23(2), p. 154-185. 
Wagner, S. H., Parker, C. P., \& Christiansen, N. D. (2003). Employees that think and act like owners: Effects of ownership beliefs and behaviors on organizational effectiveness. Personnel Psychology, Vol. 56(4), p. 847871.

Whitfield, K., Pendleton, A., Sengupta, S., \& Huxley, K. (2017). Employee share ownership and organisational performance: A tentative opening of the black box. Personnel Review, Vol. 41 (4), p. 1280-1296.

Wiseman, R. M., \& Gomez-Mejia, L. R. (1998). A Behavioral Agency Model of Managerial Risk Taking. The Academy of Management Review, Vol. 23(1), p. 133-153. Prieiga internete: https://doi.org/10.2307/259103

Zattoni, A. (2011). Who should control a corporation? Toward a contingency stakeholder model for allocating ownership rights. Journal of Business Ethics, Vol. 103(2), p. 255-274.

Zona, F. (2016). Agency models in different stages of CEO tenure: The effects of stock options and board independence on R\&D investment. Research Policy, Vol. 45(2), p. 560-575.

\section{THE MAIN FORMS AND THE DEVELOPMENT \\ OF FINANCIAL PARTICIPATION \\ OF EMPLOYEES IN LITHUANIA}

\section{Remigijus Civinskas, Rimantas Stašys}

\section{Summary}

Employee financial participation, sharing profits or property with employees, is a common social phenomenon in West European companies. In Lithuania, the phenomenon is less prevalent. However, academics, business experts and politicians agree that this form of employee participation in corporate management is beneficial for employees and companies. Employees, as owners, can increase their income through dividends, which motivates employees to achieve higher company performance. Employee financial participation is also linked to attracting additional investment, and is relevant for start-up companies.

In recent decades, the topic of employee financial participation has become an interdisciplinary subject of research. Employee financial participation is investigated by economists, human resource management specialists, and researchers in public policy and business ethics. Researchers study whether employee engagement motivates and ensures loyalty to the company. They thus explore employee-employer relationships and interactions, involving employees in decision making related to their financial performance. Employers seek to increase the relevance to employees of the company's performance. Researchers emphasise that the application of employee shares is a complex phenomenon, making it difficult to single out specific benefits. Some studies point to the negative impact of employee financial participation on company performance, where narrow interests guide employee shareholders and the pursuit of profits, investment in research and development is reduced, and risks are not adequately managed. 
The object of the research is the financial participation of employees in Lithuanian companies. The aim of the study is to assess the development of financial participation in Lithuanian companies, after exploring the legal environment and forms of employee financial participation. The tasks of the research:

1. To describe the legal environment and support a policy of employee financial participation in Lithuania.

2. To determine the most frequently applied programmes and plans for employee financial participation in Lithuania.

3. To evaluate possibilities for the development of employees' financial participation in Lithuania.

The study was conducted with 19 semi-structured individual anonymous interviews, and one focus group. The in-depth interview was chosen, because of the relevance and importance of data collection in analysing informants' opinions. Several criteria were used to sample the informants. First, the interview was aimed at competent representatives of companies: the heads of companies' human resources and finance departments, the heads of legal departments, or the top managers of law firms representing them. Second, the informants were selected according to four criteria: 1) employees of financial organisations; 2) representatives of start-up companies; 3) companies applying employee share programmes or profit-sharing schemes; 4) multinational corporations that apply for employee share programmes in Lithuania.

The analysis of the collected qualitative research data used the agency (representative) and stakeholder's theories. These theories are mainly used to analyse employee financial participation in an integrated way, and to determine the impact of this phenomenon on employee decisions and motivation.

The historical development of employee financial participation in Lithuania as a phenomenon is quite variable. It can be grouped into four periods: 1) privatisation (1991-1999); 2) after privatisation (1999-2008); 3) financial crises (2009-2014); 4) the period of state support policy (2015-2018). However, a policy of support for employee financial participation has not been formed in Lithuania, as this area was not understood as a topical problem. The new regulation of stock options has only partially solved the so-called double taxation problem.

The volume of financial participation in Lithuania gradually decreased (except in 2020). However, a European Company Survey conducted in Europe in 2019 found that $39 \%$ of managers say that at least some employees are subject to variable bonuses linked to company or institution performance (profit-sharing schemes), and 19\% say that the sharing scheme covers at least 60\%. Employee Profit Sharing is most common in financial services companies, and least common in construction companies. In Lithuania, employee share programmes apply to only 
a few employees (the situation changed only in 2020). They are all just top executives of companies.

Stock option programmes for employees of listed companies. Extensive employee stock option programmes are applied most in Scandinavian and Lithuanian-capital companies. An analysis of the documents reveals that four of the five schemes examined are profit-sharing schemes (profits made or results achieved as bonuses for the acquisition of shares and offered to employees). One company offers employees a share purchase at a discount. The last programme has a scheme which is also called a call option. Many of the schemes set out in the schemes (profit distribution for employee shares) have similar structures. A variable remuneration bonus is usually granted to purchase shares if the employee meets the conditions for participation in the plan and agrees to participate. An analysis of the programmes' objectives has shown that most focus on employees' overall motivation, involvement and promotion. Several Lithuanian companies seek to reconcile the interests of shareholders and employees with the applied programmes.

The goals and priorities of the programmes explain only the outlines of the programme. We can view the whole picture by defining some critical elements of the content and application of the financial participation programme. In absolute numbers, most employees participate in AB Swedbank. These companies likely have between 1,000 and 1,500 employees participating in the programmes. AB Klaipédos Nafta has also included several employees in its programme. Each programme discussed above has a specific employee stock option scheme that includes fixed or otherwise determinable terms. These elements are set out in the share grant rules, or are included in share donation agreements.

The analysis of share option rules and other documents issued by companies revealed that usually the preparation, coordination and approval of conditions include:

1. The company's central structural units, which implement the rules and administer the signing of contracts.

2. The evaluation of performance results, anticipating the possible amount of shares to be granted to a particular employee.

3. Decisions regarding the approval or renewal of the programme, the expected share class, and nominal value.

4. The formation of a reserve (issue of shares) to provide shares to employees.

5. The preparation of a draft employee option agreement, which the responsible employees approve.

6. The selection of persons who can participate in the programme.

7. Informing employees and concluding contracts. 
The material obtained during the qualitative research supplemented the data obtained based on documentary analysis. In response to the advantages and disadvantages of employee stock options in their companies, informants mentioned that they are costly and require high levels of expertise in administration. The study also found that the payment of dividends to the employee satisfaction programme is critical.

Executive Stock Option Programmes. Stock options for managers and professionals working with high-risk solutions (mainly in the banking and financial sectors) are often used in Lithuanian companies. Large multinational corporations do this: ASA Orkla (Management Option Programme), AB Swedbank Group (Individual Programme 2019, IP 2019), AB SEB Group (Restricted Share Programme, 2019). Executive option schemes are also implemented by several Lithuaniancapital companies, which also have extensive schemes. The qualitative study revealed that the effectiveness of share ownership as an incentive in companies operating in Lithuania is debatable. Although representatives of companies exercising stock options in the study generally considered them to be an appropriate incentive, some informants questioned the effectiveness of this measure.

Managers of Lithuanian public or private limited liability companies donate (or sell for a symbolic price) the company's shares to employees as private individuals. And this is a widespread practice in Lithuania. In practice, there are two ways of transferring shares: 1) giving shares to employees (usually deserving ones) by consolidating the company's values (to strengthen the organisational culture) and increasing motivation; and 2) sharing business with deserving employees (usually managers). The analysis of the qualitative research revealed that the purpose of share donations is to establish specific cultural values of the organisation. These schemes are alternatives to stock options, and may be acceptable in some cases, depending on the companies' goals. They are usually associated with transferring part of the business to exceptional managers, or with the motivation of deserving employees, strengthening the organisational culture. The main disadvantage is related to the limitations of the continuity of this practice, and uncertainties in the tax environment.

The qualitative study revealed that start-up companies in Lithuania usually apply, or are preparing to apply, for stock option programmes. Some start-ups use broad schemes, and some opt for narrower ones, depending on the business philosophy, the attitude of the founders, and the established culture. Atypical schemes apply to start-ups. Hedge fund managers who offer investments to start-ups also influence the option models they choose. A qualitative study found that IT startup stock option schemes have as much as seven-year stock option programmes. In some companies, the deferral period for the acquisition of shares may be even 
longer. These companies should provide for the repurchase of shares, so that employees can sell the shares acquired. It turned out that one of the biggest start-ups, UAB Vinted, had already bought out shares from its employees several times.

\section{Conclusions}

1. The Lithuanian support policy for the financial participation of employees was launched five years ago. It aimed to extend existing regulations to the needs of businesses. The change in the existing tax regulations has also created a more favourable tax environment for applying stock options. The results of this policy have not been effective enough. First of all, legal regulation is quite confusing, and is constantly changing. The taxation of shares granted to employees and the practical application of tax incentives has remained unclear.

2. In Lithuania, four employee share ownership programmes and plans are most commonly applied: extensive employee share option programmes; granting employee stock options to executives; stock option programmes in start-ups; and shares granted by shareholders to employees.

3. It has been established that institutional factors both encourage and limit financial participation instruments in Lithuania. Extended government regulations and the more favourable taxation of stock options have incentivised companies to introduce employee share ownership programmes. The decision by multinational corporations to transfer to Lithuania stock option programmes already operating in their organisations has affected Lithuania positively. It spreads examples of good practice, and affects positively the development of employee financial participation in Lithuania. Stock option programmes in start-up companies in Lithuania should also impact the development of innovations positively. The development of employee financial participation is hampered by people's low financial literacy and the small stock market in Lithuania.

Remigijus Civinskas - docentas, daktaras (humanitariniai mokslai - istorija), Vytauto Didžiojo universiteto Politikos mokslų ir diplomatijos fakulteto Viešojo administravimo katedra.

El.paštas: remigijus.civinskas@vdu.lt 